\title{
GAMBARAN KEBIASAAN MAKAN MAKANAN KARIOGENIK DAN KERUSAKAN GIGI GERAHAM TETAP PERTAMA
}

\author{
Emma Kamelia ${ }^{1}$ \\ ${ }^{1}$ Dental Therapy, Poltekkes Kemenkes Tasikmalaya, Jawa Barat, Indonesia \\ *kamelia_emma@gmail.com
}

\begin{tabular}{l}
\hline Informasi artikel \\
\hline Sejarah artikel: \\
Diterima \\
Revisi \\
Dipublikasikan \\
\hline
\end{tabular}

ABSTRAK

Kata kunci:

Kebiasan makan, makanan

kariogenik, Kerusakan Gigi

Geraham Tetap Pertama

Tujuan dari penelitian ini adalah untuk mengetahui bambaran kebiasaan makan makanan kariogenik dan kerusakan gigi geraham tetap pertama pada anak kelas III SDN Cidadap Karangnunggal Tasikmalaya. Jenis penelitian yang digunakan adalah observasional dengan rancangan penelitian descriptive research, populasi dari penelitian ini adalah selurus siswa di SDN Cidadap Kelas III Karangnunggal Tasikmalaya berjumlah 40 orang, semua siswa dijadikan sampel penelitian. Data primer merupakan data yang diambil secara langsung menggunakan food frequency questionnaire dan pemeriksaan kerusakan gigi geraham tetap pertama dengan menggunakan indeks DMF-T, analisis data menggunakan distribusi frekuensi. Dari hasil penelitian yang telah dilakukan pada murid kelas III SDN Cidadap Kecamatan Karangnunggal Kabupaten Tasikmalaya, dapat ditarik kesimpulan sebagai berikut : 1) Hasil pemeriksaan frekuensi kebiasaan makan makanan keriogenik pada murid kelas III SDN Cidadap Karangnunggal Tasikmalaya dari jumlah 40 orang, didominasi oleh frekuensi 3-6 x sehari dan bukan pada jam makan utama; 2) Hasil pemeriksaan kerusakan gigi geraham tetap pertama dari jumlah murid 40 orang, belum terdapat kerusakan pada gigi geraham tetap pertama karena masih status kesehatan giginya didominasi karies superfisialis

Key word:

Eating habits, cariogenic food, First molars damage

\section{ABSTRACT}

The purpose of this study was to determine the habits of eating cariogenic food and damage to first permanent molars in Class III of SDN Cidadap Karangnunggal Tasikmalaya. This type of research is observational research with descriptive research design, the population of this study is as straight as students in Class III of SDN Cidadap Karangnunggal Tasikmalaya totaling 40 people, all students are used as research samples. Primary data is data taken directly using a food frequency questionnaire and examination of first permanent molars damage using the DMF-T index, data analysis using frequency distribution. From the results of research that has been conducted on class III students of SDN Cidadap, Karangnunggal District, Tasikmalaya Regency, the following conclusions can be drawn: 6 times a day and not during main mealtime; 2) The results of the examination of the first permanent molars of the pupils from the number of students 40 people, there has been no damage to the first permanent molars 
because the health status of the teeth is dominated by superficial caries

\section{PENDAHULUAN}

Kesehatan gigi dan mulut merupakan salah satu aspek dari kesehatan dan kesejahteraan tubuh secara umum dan sangat mempengaruhi kualitas kehidupan, oleh karena itu kesehatan gigi dan mulut sangat berperan dalam menunjang kesehatan tubuh seseorang (Nurhidayat, dkk., 2012), sehingga apabila seseorang mengalami gangguan atau penyakit pada gigi dan mulutnya akan berdampak pada kinerja orang tersebut (Putri, dkk., 2013).

Penyakit gigi dan mulut terutama karies dan penyakit periodontal masih banyak diderita baik oleh anak-anak maupun usia dewasa (Putri, dkk., 2013). Karies gigi merupakan penyakit jaringan keras gigi akibat aktifitas bakteri, sehingga akan terjadi pelunakan jaringan keras gigi yang diikuti terbentuknya kavitas atau rongga (Martariwansyah, 2008). Hal tersebut sangat dipengaruhi oleh beberapa masyarakat yang belum menyadari pentingnya pemeliharaan kesehatan gigi dan mulut, padahal ketika sudah terjadi gangguan penyakit gigi dan mulut merupakan penyakit pada urutan pertama yang dikeluhkan masyarakat terutama anak-anak (Herijulianti,dkk., 2001). Terbukti dari hasil Riset Kesehatan Dasar Tahun 2013, indeks $D M F-T$ di Indonesia sebesar 4,6 dengan nilai masing-masing : $D-T=1,6 ; M-T=2,9 ; F-T=0,08$; yang berarti kerusakan gigi penduduk Indonesia sebesar 460 gigi per 100 orang. Hal ini menunjukkan bahwa indeks $D M F-T$ di Indonesia tidak sesuai dengan indikator dan target yang telah ditetapkan oleh $W H O$ yaitu anak umur 12 tahun mempunyai tingkat keparahan kerusakan gigi (indeks DMF-T) sebanyak satu gigi , sehingga harus dilakukan usaha untuk menanggulanginya.

Menurut Putri, dkk., ( 2013), banyak cara untuk menanggulangi penyakit gigi dan mulut dengan berbagai pendekatan yang meliputi pencegahan yang dimulai pada masyarakat, perawatan oleh diri sendiri dan perawatan oleh tenaga professional, akan tetapi menurut Maulani (2005) berdasarkan penelitian jangka panjang menunjukkan bahwa penanggulangan penyakit gigi berlubang bukanlah semata-mata ditambal, namun yang lebih penting adalah pencegahan proses karies lebih lanjut dengan cara menjaga pola makan dan makanan yang sehat.

Pola makan adalah berbagai informasi yang memberikan gambaran mengenai macam dan jumlah bahan makanan yang dimakan setiap hari oleh satu orang dan merupakan ciri khas untuk suatu kelompok masyarakat tertentu dengan maksud tertentu seperti mempertahankan kesehatan, status nutrisi, dan mencegah atau membantu kesembuhan penyakit, sedangkan makanan yang sehat adalah makanan yang mengandung gizi seimbang, kaya akan serat dan zat yang dibutuhkan untuk perkembangan tubuh (Sulistyoningsih, 2011). Pola makan yang terbentuk sangat erat kaitannya dengan kebiasaan makan seseorang. Menurut Adriani dan Wirjatmadi (2012), secara umum faktor yang mempengaruhi terbentuknya pola makan faktor ekonomi, faktor sosio budaya, faktor agama, faktor pendidikan dan faktor lingkungan.

Pola makan dan makanan yang sehat memiliki peran yang sangat penting bagi kesehatan gigi dan mulut. Sebagaimana menurut Maulani (2005), menyatakan bahwa makanan dengan gizi yang cukup dapat mencegah timbulnya hipoplasia enamel dan memperkecil potensi untuk terkena infeksi dalam rongga mulut termasuk karies gigi dan penyakit periodontal. Berdasarkan hal tersebut maka pembentukan pola makan dan makanan yang sehat harus diterapkan sejak usia dini, terutama pada masa anak-anak prasekolah dan sekolah dasar karena perilaku mereka dan apa yang mereka percayai sedang berkembang dan kemungkinan akan menjadi kebiasaan dikemudian hari, sedangkan pada saat ini dengan perkembangan global ekonomi yang kuat, mengubah gaya 
hidup dan pola makan kearah makanan yang dapat menimbulkan penyakit kronis seperti penyakit gigi dan mulut. Makanan tersebut dikategorikan ke dalam makanan kariogenik seperti roti, biskuit, gula, permen, cokelat dan es krim yang sangat digemari oleh anakanak usia sekolah dasar. Pengulangan konsumsi karbohidrat pada makanan kariogenik yang terlalu sering menyebabkan produksi asam oleh bakteri menjadi lebih sering lagi sehingga keasaman rongga mulut menjadi lebih asam dan semakin banyak enamel yang terlarut (Rahmadhan, 2010).

Sekolah Dasar (SD) merupakan suatu kelompok yang sangat strategis untuk penanggulangan kesehatan gigi dan mulut terutama pada usia 8-11 tahun merupakan kelompok usia yang sangat kritis terhadap terjadinya karies gigi tetap karena pada usia ini mempunyai sifat khusus yaitu masa transisi pergantian gigi susu ke gigi tetap. Terbukti menurut Nurhidayat, dkk., (2012), menyatakan bahwa pada usia 8-11 tahun prevalensi karies gigi mencapai $60 \%-80 \%$, oleh sebab itu setiap orang tua harus waspada ketika telah muncul gigi tetap, untuk jenis gigi seri (incisivus), gigi taring (caninus), dan gigi geraham kecil (premolar), diberi tanda akan munculnya gigi tetap dengan kegoyangan dan tanggalnya gigi susu, namun khusus untuk gigi geraham (molar) tetap pertama, harus diingat bahwa gigi itu tidak menggantikan gigi susu apapun. Gigi tetap tersebut muncul di belakang gigi geraham (molar) susu yang terakhir. Seandainya perawatan gigi belum terbentuk, gigi geraham (molar) tetap pertama ini rawan terjadi kerusakan dan seringkali harus dikorbankan dengan suatu pencabutan karena tidak bisa tertolong lagi. Banyak orang tua yang beranggapan gigi tersebut masih bisa tergantikan oleh gigi geraham (molar) lainnya (Maulani, 2005). Berdasarkan latar belakang masalah tersebut maka tujuan dari penelitian ini adalah untuk mengetahui bambaran kebiasaan makan makanan kariogenik dan kerusakan gigi geraham tetap pertama pada anak kelas III di SDN Cidadap Kecamatan Karangnunggal Kabupaten Tasikmalaya

\section{METODE}

Jenis penelitian yang digunakan adalah observasional dengan rancangan penelitian descriptive research yaitu penelitian yang dilaksanakan untuk melihat adanya gambaran tentang variabel yang akan diteliti (Arikunto, 2002). Seluruh murid di Sekolah Dasar Negeri Cidadap Kelas III Kecamatan Karangnunggal Kabupaten Tasikmalaya berjumlah 40 orang, teknik pengambilan sampel dalam penelitian ini diperoleh dengan cara total sampling. Data primer merupakan data yang diambil secara langsung oleh peneliti dari hasil penilaian kebiasaan makan makanan kariogenik dengan menggunakan food frequency questionnaire dan pemeriksaan kerusakan gigi geraham tetap pertama dengan menggunakan indeks $D M F-T$. Hasil penelitian dengan memberikan lembar ceklis Food Frequency Questionnaire untuk memeriksa kebiasaan makan makanan kariogenik, dan pemeriksaan kerusakan gigi geraham tetap pertama menggunakan lembar pemeriksaan $D M F-T$ diolah dalam program excel dan disajikan dalam bentuk distribusi frekuensi.

\section{HASIL DAN PEMBAHASAN}

Lokasi penelitian dilaksanakan di Sekolah Dasar Negeri Cidadap Kecamatan Karangnunggal Kabupaten Tasikmalaya, dengan kegiatan sebagai berikut : 1) pengisian lembar ceklis Food Frequency Questioner dan pemeriksaan kerusakan gigi geraham tetap pertama dengen menggunakan lembar DMF-T. Hasilnya adalah sebagai berikut: 
Tabel 1. Distribusi Frekuensi Hasil Frekuensi Makanan Kariogenik yang Dikonsumsi Murid Kelas III Sekolah Dasar Negeri Cidadap Kecamatan Karangnunggal Kabupaten Tasikmalaya

\begin{tabular}{ccc}
\hline Frekuensi makanan kariogenik yang dikonsumsi & n & \% \\
\hline 3-6 x sehari & 23 & 57,5 \\
\hline 2 x sehari & 7 & 17,5 \\
\hline 1 x sehari & 8 & 20 \\
\hline Tidak pernah & 2 & 5 \\
\hline Total & $\mathbf{4 0}$ & $\mathbf{1 0 0}$ \\
\hline
\end{tabular}

Berdasarkan tabel diatas menunjukan bahwa responden mengkonsumsi makanan kariogenik tertinggi sebanyak 3-6 x sehari sebanyak 23 orang ( 57,5\%). Jenis makanan kariogenik terdapat pada tabel 2.

Tabel 2. Distribusi Frekuensi Kebiasaan Makan Makanan Kariogenik per Hari Murid Kelas III Sekolah Dasar Negeri Cidadap Kecamatan Karangnunggal Kabupaten Tasikmalaya

\begin{tabular}{|c|c|c|c|c|c|c|c|c|c|c|c|}
\hline \multirow{4}{*}{ No. } & \multirow{4}{*}{$\begin{array}{c}\text { Jenis } \\
\text { makanan } \\
\text { kariogenik } \\
\text { yang } \\
\text { dikonsumsi }\end{array}$} & \multicolumn{8}{|c|}{ Frekuensi pola makan } & \multirow{3}{*}{\multicolumn{2}{|c|}{ Jumlah }} \\
\hline & & & & \multicolumn{4}{|c|}{ Hari } & \multirow{2}{*}{\multicolumn{2}{|c|}{$\begin{array}{c}\text { Tidak } \\
\text { pernah }\end{array}$}} & & \\
\hline & & \multicolumn{2}{|c|}{$1 x$} & & $\mathbf{x}$ & & & & & & \\
\hline & & $\mathbf{n}$ & $\%$ & $\mathbf{n}$ & $\%$ & n & $\%$ & n & $\%$ & $\mathbf{n}$ & $\%$ \\
\hline 1 & Es Krim & 8 & 20 & 14 & 35 & 18 & 45 & 0 & 0 & 40 & 100 \\
\hline 2 & Roti & 10 & 25 & 6 & 15 & 23 & 57,5 & 1 & 2,5 & 40 & 100 \\
\hline 3 & Permen & 2 & 5 & 7 & 17,5 & 31 & 77,5 & 0 & 0 & 40 & 100 \\
\hline 4 & Cokelat & 10 & 25 & 4 & 10 & 23 & 57,5 & 3 & 7,5 & 40 & 100 \\
\hline 5 & Snack & 9 & 22,5 & 3 & 7,5 & 24 & 60 & 4 & 10 & 40 & 100 \\
\hline
\end{tabular}

Tabel diatas menunjukkan hasil bahwa responden memiliki kebiasaan mengkonsumsi jenis makanan kariogenik setiap harinya. Setelah dirata-ratakan hasilnya responden mengkonsumsi makanan kariogenik tertinggi sebanyak 3-6 x sehari sebanyak 23 orang ( $57,5 \%$ ), selanjutnya 2 x sehari sebanyak 7 orang (17,5\%), 1 x sehari sebanyak 8 orang ( $20 \%$ ), dan tidak pernah sebanyak 2 orang (5\%). Kemudian hasil Pemeriksaan Kerusakan Gigi Molar Tetap Pertama sebagai berikut:

Tabel 3. Distribusi Frekuensi Kerusakan Gigi Molar Tetep Pertama Secara Umum pada Murid Kelas III Sekolah Dasar Negeri Cidadap Kecamatan Karangnunggal Kabupaten Tasikmalaya

\begin{tabular}{ccc}
\hline Status Karies Gigi & n & \% \\
\hline Karies & 36 & 90 \\
\hline Tidak karies & 4 & 10 \\
\hline Jumlah & $\mathbf{4 0}$ & $\mathbf{1 0 0}$ \\
\hline
\end{tabular}

Berdasarkan tabel diatas menunjukkan bahwa dari jumlah murid sebanyak 40 orang, murid yang terkena karies pada gigi molar tetap pertama sebanyak 36 orang (90\%), sedangkan yang free karies hanya 4 orang (10\%) dari jumlah murid sebanyak 40 orang. Kemudian kerusakan gigi molar tetap pertama berdasarkan eleman gigi 


\section{Tabel 12. Distribusi Frekuensi Kerusakan Gigi Molar Tetep Pertama Berdasarkan Elemen Gigi Pada Murid Kelas III Sekolah Dasar Negeri Cidadap Kecamatan Karangnunggal Kabupaten Tasikmalaya}

\begin{tabular}{|c|c|c|c|c|c|}
\hline & \multicolumn{4}{|c|}{ Elemen Gigi } & \multirow[t]{2}{*}{ Total } \\
\hline & 16 & 26 & 36 & 46 & \\
\hline $\begin{array}{l}\text { Jumlah } \\
\text { Elemen } \\
\end{array}$ & 12 & 12 & 30 & 34 & 88 \\
\hline $\begin{array}{c}\text { Persentasi } \\
(\%)\end{array}$ & 13,63 & 13,63 & 34,10 & 38,64 & 100 \\
\hline
\end{tabular}

Berdasarkan tabel diatas menunjukkan bahwa elemen gigi yang paling banyak terserang karies adalah gigi 46 sebanyak 34 eleman (38,64\%), dan gigi yang paling sedikit terserang karies adalah gigi 16 dan 26 sebanyak 12 elemen $(13,63 \%)$. Hasil terakhir yaitu mengenai kerusakan gigi molar tetap pertama berdasarkan kedalaman karies

Tabel 13. Distribusi Frekuensi Kerusakan Gigi Molar Tetep Pertama

Berdasarkan Kedalaman Karies Pada Murid Kelas III Sekolah Dasar Negeri Cidadap Kecamatan Karangnunggal Kabupaten Tasikmalaya

\begin{tabular}{|c|c|c|c|c|c|}
\hline \multirow{2}{*}{ Elemen Gigi } & \multicolumn{4}{|c|}{ Kedalaman Karies } & \multirow{2}{*}{ Jumlah } \\
\hline & KME & KMD & KMP & KMA & \\
\hline 16 & 9 & 1 & 2 & 0 & 12 \\
\hline 26 & 10 & 0 & 1 & 1 & 12 \\
\hline 36 & 20 & 1 & 4 & 5 & 30 \\
\hline 46 & 25 & 0 & 5 & 4 & 34 \\
\hline Jumlah elemen & 64 & 2 & 12 & 10 & 88 \\
\hline
\end{tabular}

Berdasarkan tabel diatas menunjukkan bahwa bahwa elemen gigi yang terserang karies berdasarkan kedalaman karies adalah karies mencapai enamel sebanyak 64 gigi dan yang paling sedikit terserang karies adalah karies mencapai dentin sebanyak 2 gigi. Jenis makanan kariogenik yang sering dikonsumsi menurut hasil penelitian yang telah dilakukan yaitu : roti, permen, eskrim, cokelat, dan snack. Makanan-makanan tersebut bersifat manis dan menarik, sehingga anak-anak menyukai makanan tersebut. Hal ini sama dengan penelitian yang dilakukan pada anak SDN Cihaur Kecamatan Jatiwaras , bahwa sebagian besar anak sekolah sangat suka makanan yang manis, lunak, melekat (bersifat kariogenik) dan makanan yang bentuknya menarik. Meningkatnya konsumsi makanan-makanan tersebut yang kebanyakan mengandung gula, maka sering sulit bagi anak untuk menghindari konsumsi gula yang banyak (Barus, 2008, cit, Kartikasari, 2013).

Makanan manis akan dinetralisir oleh air ludah setelah 20 menit, maka apabila setiap 20 menit sekali mengkonsumsi makanan manis akan mengakibatkan banyak sisa makanan yang menempel yang kemudian menjadi plak sehingga gigi lebih cepat rusak (Wong, dkk., 2008). Hal ini didukung oleh Suwelo (1992), yang menyatakan bahwa plak yang mengandung bakteri merupakan awal terbentuknya karies. Bagian gigi yang memudahkan pelekatan plak sangat mungkin terserang karies. Bagian-bagian yang mudah terserang karies yaitu pit dn fissure pada permukaan oklusal molar. Gigi molar rahang bawah terdapat pit fisure yang cukup dalam dibanding gigi molar rahang atas sehingga memudahkan retensi makanan dan kebiasaan anak-anak usia sekolah dasar sering 
memakan makanan atau minuman sukrosa yang dapat menyebabkan kondisi kebersihan mulut pada anak-anak lebih buruk dibandingkan orang dewasa.

Makanan manis lebih baik dimakan pada saat jam makan utama, seperti sarapan, makan siang, dan makan malam, karena pada waktu jam makan utama biasanya air ludah yang dihasilkan cukup banyak, sehingga dapat membantu membersihkan gula dan bakteri yang menempel pada gigi, sedangkan dari hasil penelitian menunjukkan bahwa konsumsi makanan kariogenik didominasi oleh frekuensi 3-6 x sehari dan bukan pada waktu jam makan utama sehingga resiko terserang karies sangat tinggi. lamanya waktu yang dibutuhkan terjadinya proses karies sangat bervariasi antara 6-48 bulan. Pada golongan anak sering terjadi serangan karies dalam kurun waktu 2-4 tahun sesudah erupsi gigi,berarti untuk gigi molar tetap pertama akan mudah terserang pada usia 9- 12 tahun (Wong, dkk.,2008), dan hasil penelitian kerusakan gigi molar tetap pertama pada anak kelas III SDN Cidadap diperoleh hasil anak yang gigi molar tetap pertamanya terserang karies sebanyak 36 orang (90\%), sedangkan yang free karies sebanyak 4 orang (10\%).

Hasil penelitian kerusakan gigi molar tetap pertama berdasarkan elemen gigi yang terkena karies diperoleh jumlah gigi yang lebih banyak terkena karies yaitu gigi 36 dan 46 sebanyak 64 gigi $(72,26 \%)$, sedangkan jumlah gigi yang sedikit terkena karies yaitu gigi 16 dan 26 sebanyak 24 gigi (27,26 \%),. Hal ini sesuai dengan pendapat Suwelo (1992), bahwa posisi gigi molar rahang bawah memiliki pit fissure yang lebih dalam dibanding gigi molar rahang atas sehingga memudahkan perlekatan sisa makanan, pendapat ini ditegaskan oleh Tarigan (2013) yang mengatakan bahwa karies dapat disebabkan oleh berbagai sebab diantaranya yaitu karbohidrat, mikroorganisme, saliva, permukaan dan bentuk gigi. Karbohidrat yang tertinggal di dalam mulut dan mikroorganisme merupakan penyebab dari terjadinya karies gigi. Hasil penelitian berdasarkan kedalaman karies diperoleh karies superfisialis sebanyak 64 gigi dan karies media sebanyak 2 gigi, serta karies propunda sebanyak 12 gigi dan indikasi pencabutan sebanyak 10. Pencegahan sedini mungkin dapat menghambat penyebaran karies lebih lanjut.

Menurut Be Kien Nio (1989), menjelaskan bahwa faktor-faktor yang mempengaruhi terjadinya karies gigi adalah : a) diet yaitu makanan manis (sukrosa) yang menyebabkan karies gigi; b) plak yaitu suatu endapan lunak yang menutupi gigi dan melekat pada permukaan gigi; c) enamel yaitu lapisan terluar pada gigi. Menurut Houwink, dkk. (1993) dalam menjaga kebersihan gigi dan mulut dapat dilakukan pencegahan melalui makanan (bebas gula), kebersihan mulut (menyikat gigi, berkumur, penggunaan benang gigi), melalui fluoride (tablet) untuk anak-anak, pasta gigi yang mengandung fluoride dan dengan kunjungan ke dokter gigi untuk kontrol. Selain menjaga kebersihan gigi dan mulut, karies jaga dapat dicegah yaitu dengan cara : a) menghilangkan plak karena karies terjadi pada tempat dimana ada plak, maka penyikatan gigi yang benar dibantu oleh pembersihan interdental dengan benang gigi merupakan cara pencegahan yang baik; b) pemberian fluoride, pemberian fluoride sangat efektif untuk mencegah karies yaitu melalui air minum, garam dapur, tablet, pasta gigi, berkumur-kumur dan pemberian secara individual; c) penutupan fissure (fissure sealent), penutupan fissure yaitu mengisi fissure dan cekungancekungan dengan resin setelah enamelnya di etsa, terbukti merupakan cara pencegahan yang efisien untuk mencegah karies lebih lanjut ( Schuurs, AHB., 1990)

\section{KESIMPULAN}

Dari hasil penelitian yang telah dilakukan pada murid kelas III SDN Cidadap Kecamatan Karangnunggal Kabupaten Tasikmalaya, dapat ditarik kesimpulan sebagai berikut : 1) Hasil pemeriksaan frekuensi kebiasaan makan makanan keriogenik pada murid kelas III SDN Cidadap Kecamatan Karangnunggal Kabupaten Tasikmalaya dari jumlah 40 orang, didominasi oleh frekuensi 3-6 x sehari dan bukan pada jam makan utama; 2) Hasil 
pemeriksaan kerusakan gigi geraham tetap pertama dari jumlah murid 40 orang, belum terdapat kerusakan pada gigi geraham tetap pertama karena masih status kesehatan giginya didominasi karies superfisialis

\section{DAFTAR PUSTAKA}

Adriani, M., dan Wirjatmadi, B., 2012, Peranan Gizi dalam Siklus Kehidupan, Kencana, Jakarta.

Ali, M., 2009, Pendidikan untuk Pembangunan Nasional, Imperial Bhakti Utama, Bandung.

Arikunto, 2002, Metode Penelitian, Erlangga, Jakarta.

Cameron, A., dan Richard, W., 2008, Handbook of Dentistry, Toronto, Mosby

Chemiawan, E., Gartika, M., Indriyanti R., 2004, Perbedaan Prevalensi Karies pada Anak Sekolah Dasar dengan Program UKGS dan Tanpa UKGS Tahun 2004, Journal Kedokteran Gigi, Lembaga Penelitian FKG Universitas Padjajaran, Bandung

Departemen Kesehatan R.I., 1995, Tata Cara Kerja Pelayanan Asuhan Kesehatan Gigi dan Mulut di Puskesmas, Depkes.R.I., Jakarta

Ford, T.R., dan Pitt, 1993, Restorasi Gigi, CV. EGC, Jakarta

Herijulianti, E., Indriani, T.S., dan Artini, S., 2001, Pendidikan Kesehatan Gigi, CV. EGC, Jakarta.

Hongini,S., dan Aditiawarman, M., 2012, Kesehatan Gigi dan Mulut, Pustaka Reka Cipta, Bandung.

Houwink, B., Dirks, B., Cramwinckel, A.B., Crielaers, P.J.A., Dermaut, L. R., ijkman, M.A.J., Huis In't Veld, J.H.J., Konig, K.G., Moltzer, G., Van Palenstein Helderman, W.H., Roukema, P.A., Pilot, T., Schautteet, H., Tan, H.H., Van De Velden-Veldkamp, I., Woltgens, J.H.M., 1993, Ilmu Kedokteran Gigi encegahan, Gadjah Mada University Press:Yogyakarta.

Itjingningsih, W.H., 2012, Anatomi Gigi, CV. EGC, Jakarta.

Kartikasari, HY., 2013, Hubungan Kebiasaan Makan dan Pemeliharaan Kesehatan Gigi dengan Karies Gigi Pada Anak SD 060935 Jalan Pintu Air II Simpang Gudang Kota Medan Tahun 2008, Skripsi, Universitas Sumatera Utara, Medan

Kartono, K., 2007, Psikologi Anak, CV, Mandar Maju, Bandung.

Kementerian Kesehatan, R.I., 2013, Riset Kesehatan Dasar, BPPK Kemenkes, R.I., Jakarta.

Kidd, E., Joyston, S., dan Bachel, 2002, Dasar - dasar Penyakit Karies dan Penanggulangannya, CV, EGC, Jakarta.

Martariwansyah, 2008, Gigiku Kuat Mulutku Sehat, Karya Kita, Bandung.

Maulani, C., 2005, Kiat Merawat Gigi Anak, PT. Gramedia, Jakarta.

Nurhidayat, O., Tunggul, E,P., dan Wahyono, B., 2012, Perbandingan Media Power Point dengan Flip Chart dalam Meningkatkan Pengetahuan 
Kesehatan Gigi dan Mulut, Unes Journal of Public Healt, http://journal.ac.id/sju/index.php/ujph, diakses : 9 Januari 2015.

Phinkam, J,R.,2005, Pediatric Dentistry, Philadelpia, W.B. Saundersco.

Putri, M.H., Herijulianti, E., dan Nurjaman, N., 2013, Ilmu Pencegahan Penyakit Jaringan Karas dan Jaringan Pendukung Gigi, CV. EGC, Jakarta.

Rahmayani, E., 2008, Hubungan Pola Makan dan Tingkat Kebersihan Gigi dan Mulut dengan Pengalaman Karies Gigi Anak Sekolah Dasar Kelas V di SDN Neglasari 1 Kecamatan Kadungora Kabupaten Garut, Karya Tulis Ilmiah JKG Poltekes Tasikmalaya, Tasikmalaya

Rahmadhan, AG. 2010. Serba Serbi Kesehatan Gigi dan Mulut, Jakarta.

Sulistyoningsih, H., 2011, Gizi untuk Kesehatan Ibu dan Bayi, Graha Ilmu, Yogyakarta

Supariasa, I. D., Bakri, B., dan Fajar, I., 2013, Penilaian Status Gizi, CV. EGC, Jakarta

Suwelo, IS., 1992, Karies Gigi Pada Anak dengan Berbagai Faktor Etiologi, ECG, Jakarta.

Tarigan, R., 2013, Karies Gigi, Hipokarates, Jakarta.

Wong, DL., 2008, Buku Ajar Keperawatan Pediatrik, EGC, Jakarta. 